\title{
Differential expression of eight defensin genes of $N$. benthamiana following biotic stress, wounding, ethylene, and benzothiadiazole treatments
}

Bahman Bahramnejad • L. R. Erickson •

C. Atnaseo · P. H. Goodwin

Published online: 7 August 2009

(C) Springer-Verlag 2009

Erratum to: Plant Cell Rep (2009) 28:703-717

DOI 10.1007/s00299-009-0672-8

Unfortunately, the first name and last name of one of the co-author has been wrongly published. The correct name is C. Atnaseo and not A. Chuthamat.

The online version of the original article can be found under doi:10.1007/s00299-009-0672-8.

B. Bahramnejad ( $\square)$

Department of Plant Breeding,

University of Kurdistan, Sanandaj, Iran

e-mail: b.bahramnejad@uok.ac.ir

B. Bahramnejad · L. R. Erickson - C. Atnaseo

Department of Plant Agriculture,

University of Guelph,

Guelph, ON N1G 2W1, Canada

P. H. Goodwin

Department of Environmental Biology,

University of Guelph, Guelph, ON N1G 2W1, Canada 